\title{
No language requirement: Translation theory in a general education context
}

DOI:

10.1080/07374836.2014.931269

\section{Document Version}

Accepted author manuscript

Link to publication record in Manchester Research Explorer

\section{Citation for published version (APA):}

Strowe, A., \& Farley, S. K. (2014). No language requirement: Translation theory in a general education context. Translation Review, 89(1), 15-34. https://doi.org/10.1080/07374836.2014.931269

\section{Published in:}

Translation Review

\section{Citing this paper}

Please note that where the full-text provided on Manchester Research Explorer is the Author Accepted Manuscript or Proof version this may differ from the final Published version. If citing, it is advised that you check and use the publisher's definitive version.

\section{General rights}

Copyright and moral rights for the publications made accessible in the Research Explorer are retained by the authors and/or other copyright owners and it is a condition of accessing publications that users recognise and abide by the legal requirements associated with these rights.

\section{Takedown policy}

If you believe that this document breaches copyright please refer to the University of Manchester's Takedown Procedures [http://man.ac.uk/04Y6Bo] or contact uml.scholarlycommunications@manchester.ac.uk providing relevant details, so we can investigate your claim.

\section{OPEN ACCESS}


This is an Accepted Manuscript of an article published by Taylor \& Francis in Translation Review in August 2014, available online: http://www.tandfonline.com/doilfull/10.1080/07374836.2014.931269.

The following link is for eprint access, and is limited to the first 50 uses: http://www.tandfonline.com/eprint/T9MZfHAnBdqw9etCWNXg/full.

\section{No Language Requirement: Translation Theory in a General Education Context ${ }^{1}$ Anna Strowe Shannon Farley}

\section{Introduction}

When the description of our new course on translation theory at the undergraduate level was emailed to faculty in the Comparative Literature program at the University of Massachusetts in late December 2011, it was met with some consternation. At issue was not the discipline of translation studies or the value of teaching it to undergraduates, but a single line at the end of the course description: "Competence in a language other than English is helpful, but not necessary." How could we teach translation, especially when we said that students would be given actual translation exercises in discussion sections, if no foreign language was required? We have now run the course, Comp Lit 290T, three times, in Spring 2012, Fall 2012, and Spring 2013, and although most of our 59 students over those three semesters had some experience with a foreign language, others identified themselves as not knowing any language other than English. This article explores our rationale as well as some of our methods for teaching translation theory, a set of powerful hermeneutic tools that can be incorporated into literary study as well as many other fields, for a general education student in a potentially monolingual classroom.

\footnotetext{
1 The authors would like to thank Maria Tymoczko for her support in designing the class as well as for serving as the instructor of record for the first experimental semester. We would also like to recognize the Comparative Literature Unit, the Department of Languages, Literatures, and Cultures, and the College of Humanities and Fine Arts at the University of Massachusetts for their support of this course.
} 
No Language Requirement:

Translation Theory in a General Education Context

Strowe and Farley

The field of translation and translation studies has gained considerable attention in the past decade. The Presidential Theme of the 2009 MLA Conference was "The Tasks of Translation in the Global Context," tapping into a translational zeitgeist that has manifested in many other ways as well. In U.S. institutions, there is an ever-increasing number of programs in translation, including new certificate programs, concentrations, majors, and minors at both the undergraduate and graduate levels, and elsewhere new courses in existing fields that address questions of translation. ${ }^{2}$ More and more job listings in related fields, such as English literature, world literature, and national literature departments, are including translation studies as a desirable secondary specialization or translator training as a primary area.

Accompanying this increase in interest in the field is, naturally, a surge of scholarly production related to translation. David Damrosch and Emily Apter have published significant work on the position of translation in literary study, and particularly in the context of world and comparative literature. The cultural turn in translation studies identified by Susan Bassnett and André Lefevere (1990) has brought translation to the attention of many scholars of literature and culture and drawn attention to translation theory as a methodological tool. Translation has also found its way into literary study of all sorts as a a hermeneutic process and a metaphor for transmission and interpretation, the latter occasionally by scholars who seem unaware of the vast body of extant theoretical literature.

These new approaches of Damrosch, Apter, and others answer in part Lawrence Venuti's advocacy for a "pedagogy of translated literature" (Venuti 331), but they are far from the only

2 The websites of the American Translators Association (ATA) and the American Literary Translators Association (ALTA) and each have lists of programs in translation (American Translators Association, American Literary Translators Association). The ATA has also published the volume Programs in Translation Studies: An ATA Handbook, which is available for purchase on their website, and is held in two U.S. university libraries listed on WorldCat (Champe). Due to the exceptional growth in the field, this last resource, published in 2002, is out of date; the ATA list is limited as it includes only programs run by its own institutional members, and the ALTA list is difficult to search, as it includes only department names and languages, with links, but without program descriptions. 
No Language Requirement:

Translation Theory in a General Education Context

Strowe and Farley

scholars to do so. An article in College English by Emily O. Wittman and Katrina Windon titled

“Twisted Tongues, Tied Hands: Translation Studies and the English Major" presented their

method of approaching translation in an English department. The class they discussed, an

undergraduate course that aimed at "identifying the texts, the theories, and even the tangents

necessary to make [a mandatory course on translation studies for English majors] relevant to the department, the students, and the future of English studies" (Wittman and Windon 449). Other recent scholarship on a translational pedagogy of literature includes the essays in the volume Literature in Translation: Teaching Issues and Reading Practices, edited by Carol Maier and Francoise Massardier-Kenney and published by St. Jerome (2010). In her chapter “Translation Theory and Its Usefulness," Françoise Massardier-Kenney highlights four themes in translation studies and translation theory that she sees as particularly relevant to the study of literature in translation. She observes that "an awareness of these theoretical considerations will allow the readers of translations to understand why certain choices have to be made at certain times and to appreciate the constraints under which translators operate at different times and in different countries" (28).

Our work in creating this course focused on the teaching of translation theory, clearly associated with a "pedagogy of translated literature," but also a theoretical paradigm in its own right, and one not limited to literary translation. Windon and Wittman write that the course they describe in their article "falls somewhere in between" what they identify as the extremes of translation studies programs: "the purely pragmatic (translator training) [and] the purely theoretical" (451). Our course both embraces a position at the theoretical end and rejects the classification. Using the term "theory" in its most rigorous scientific sense, referring to the collection of statements about translation processes and products that begin as hypotheses and 
No Language Requirement:

Translation Theory in a General Education Context

Strowe and Farley

are supported through observation and analysis, our course is a course in translation theory. At the same time, however, and because of the same definition of theory, we reject the notion that translator training is somehow "untheoretical" or cannot be theorized. The approach to translation theory in our course is not an approach to "theory" in the sense of "abstract opinion" to be contrasted with practice. It is an attempt to introduce students to translation theory as a set) of hermeneutic tools and approaches to be used in any future academic (and non-academic) endeavor.

Our approach also differs from that of Windon and Wittman in its intellectual direction.

In introducing their course, Windon and Wittman write (450) that "Reading in and about translation significantly enriches our understanding of the genealogy of texts and encourages us to think about the way that original texts are often obfuscated through translation." We believe that this is indeed the case, although one might take issue with the notion of "original" or the valences of a genealogical approach to literature. Our own course, however, is intended to move from text to theory, from the manifestations of literary and non-literary texts to theorizations about the nature of communication and textual exchange and modification. Of course, neither of these intellectual movements is entirely self-contained, and our work, like that of Windon and Wittman, does indeed give students tools to perform the types of close reading of world literature that Windon and Wittman aim for, along with Wai Chee Dimock, Terry Eagleton, and Lawrence Venuti, whom Windon and Wittman cite (449 ff.).

We present our course not, then, as a replacement for any particular previous approaches, but as a supplement to them. The very broadening nature of the field that inspired Windon and Wittman begs this work. We believe that our approach, taken either on its own or in concert with 
No Language Requirement:

Translation Theory in a General Education Context

the approaches of other scholars, can help the academy come to terms with the scope and possibilities of the field of translation studies.

\section{Course Motivations and Foundations}

The parallel question to how one could teach translation and translation theory to monolingual students, is of course why one would. Many universities have language requirements for graduation and some even for entrance. In an increasingly global society, such requirements are justified as providing linguistic and cultural information to help students understand their world, and, as language teachers know, learning a foreign language often teaches students about their native language as well. Language learning can certainly help create well-adjusted, culturally-sensitive world citizens, but two semesters, or two years, of language study, even by a student who is linguistically gifted, will not necessarily give them insight into the intricacies of multicultural, multilingual, intertextual global communications. The skills and abilities that translation studies offers are another way to approach issues of intercultural communication, understanding, and the interpretation of texts of all kinds from diverse contexts. Wittman and Windon write (452) that "there is a clear need ... for the study of translation, perhaps especially for the monolingual student who will read foreign literatures exclusively in translation." The volume edited by Maier and Massardier-Kenney (2010) addresses this same need, and Massardier-Kenney (2010) provides an articulate explanation of why and how certain themes in translation studies assist with student understanding. Expanded to include non-literary texts and questions of cultural exchange, this sense of the importance of translation grounds our work as well.

Before proceeding further, we must reiterate the distinction in the field of translation between the teaching of translation and the teaching of translation theory. Our course was not 
No Language Requirement:

Translation Theory in a General Education Context

designed to teach students how to be good translators, although one of the results, as we will see, is that students gain the type of perspective on cultural difference and interlingual communication that can improve their abilities as translators, given familiarity with another language. Our approach to teaching translation theory, however, is aimed more at examining possible explanations and statements about the observed phenomena of interlingual, intercultural communication and giving the students the tools to apply these observations to additional cases and situations, including situations of intralingual and intersemiotic communication. Maria Tymoczko's recent article on translation theory for the Encyclopedia of Applied Linguistics ("Translation Theory") provides a synthetic account of the role of theory in the field of translation; it is a text that we assigned in the first week of class. For this class, this distinction is fundamental: the difference between the practice of translation by (presumably) nonmonolingual students and the exploration of the theory of translation by all kind of students, taking theory in a scientific sense not as a guide to practice but as an overarching conceptual framework that explains practices and products, as well as their effects on global communication.

A second, related distinction, which we indicated briefly above, is that we were also not trying to teach literature in translation, or to examine only the issues involved in the theorization and teaching of world literature, although the tools of translation theory can certainly be turned to such topics. The discipline of translation theory can supplement and augment literary study, as many of the scholars mentioned above have observed, but its purview extends far beyond those limits. As such, our course is perhaps an unusual animal: an undergraduate general education course in literature that provides fundamental tools for literary study and explores global literary products during the course of the semester, but which consists mainly of theoretical readings. 
No Language Requirement:

Translation Theory in a General Education Context

Given this goal of teaching theory to undergraduates, it remains to discuss why such a course would be useful to both monolingual and non-monolingual students. As André Lefevere argues in his 1991 Translation, Rewriting, and the Manipulation of Literary Fame, an excerpt of which we assign early in the semester, translation is a form of rewriting which, along with summarizing, anthologizing, criticizing, and historicizing, supplies the majority of "nonprofessional readers" with their knowledge about any given text (1 et passim). Most of the students who take Comp Lit 290T enroll for General Education credit, not because they are planning to become professional translators. These students are included in Lefevere's category of "non-professional readers" but by educating them about the process of translating we encourage meta-cognition about all kinds of texts and their/manipulation, in other words, the development of certain "professional" reading skills. Students learn about different modes of textual interpretation and the specific ways that they can apply those modes to all kinds of texts.

The concrete results of the learning of these modes can be seen in the responses we received at the end of the semester from students who cannot help but see almost every text they encounter as a kind of translation, or at least, as an interpretive narrative that has its origins in a particular point of view. This ability to see textual manipulation is a critical skill in an age where news media privilege the narrative over the facts, and any individual with a computer, tablet, or smartphone and an internet connection can publish her point of view to the world at large. Rather than resorting to appeals to authority and warning students to distrust everything they read on the internet, our course teaches them the skills they need to see the text behind the text and make judgments based on what they see. Translation theory provides models and vocabulary to describe intertextuality that, in addition to helping to explain new modes of literature and New Media, can demonstrate the connections between literatures as well as between literature and 
No Language Requirement:

Translation Theory in a General Education Context

culture. More specifically, students who take our class strengthen their close reading skills as they explore and explain translators' word choices through the case studies in theoretical articles, as well as through their own analyses of texts that we bring in to class as examples and the texts they choose to work with for class projects. Finally, students taking this course broaden their own cultural competencies, which are integral both to understanding culture and to expressing oneself within it.

\section{Course Readings}

The nature of the course, a single-semester, 200-level general education course with 1.5 contact hours per week, combined with the breadth of the discipline meant that we had to make very careful decisions about our reading list. Any number of excellent reading lists could be created for a course like the one we designed with very little overlap of authors, much less texts. Our choices included scholars such as Itamar-Even Zohar, Edwin Gentzler, Theo Hermans, James Holmes, Moira Inghilleri, Roman Jakobson, André Lefevere, W.V.O. Quine, Friedrich Schleiermacher, Maria Tymoczko, and Lawrence Venuti, to name only a few. ${ }^{3}$

The creation of our bibliography was not without difficult and much-debated decisions.

Our desire to introduce the fundamental concepts of translation theory led us to omit, for example, the work of David Damrosch and Emily Apter as more oriented towards a pedagogy of literature in translation. Similar decisions regarding time constraints, our desire to construct the course around particular thematic notions, and the need to find texts that would be understandable to undergraduates with little experience in literary study and less in literary criticism led to the omission from the reading list of other notable scholars, including Susan Bassnett, David Bellos, Suzanne Jill Levine, Tejaswini Niranjana, Katharina Reiss, Douglas Robinson, Rainer Schulte, Sherry Simon, Mary Snell-Hornby, Gayatri Chakravorty Spivak,

\footnotetext{
3 The reading list for the Fall 2012 edition of the course is included in Appendix B.
} 
No Language Requirement:

Translation Theory in a General Education Context

Strowe and Farley

Harish Trivedi, Hans Vermeer, Michael Wood, and many others whose work has been and

continues to be fundamental to translation theory. Although not included in the reading list, the

work of some of these scholars, and the topics they address, were often brought up in lectures

and class discussions, and their work is often cited in the texts that we did assign. ${ }^{4}$

\section{Breaking Down Translation}

In order to convince students, however, of the wide variety of applications for translation

theories and the conclusions that we can draw from the study of translation and translations, we

first needed to disrupt their sense that they already knew what a translation was, and the general

outline of how one might make one. Our class began with an exploration not of translation

proper, but of what G.C. Kálmán terms "borderline cases” (Kálmán) and examples we discussed

as "limiting cases" of translation: literary activities that in some ways seem to be translational

but at the same time defy such a categorization. We discussed a number of such limiting cases in

the first few weeks, along with concepts like Lefevere's rewriting, before introducing Kálmán’s

terminology as the specific framework of the third week, which included a discussion of that

perennial favorite of translation studies, "Pierre Menard, Author of the Quijote" (Jorge Luis

Borges). The aim of this oblique approach was to immediately challenge students' idea that they

knew what a translation was.

Another example of a limiting case that we examined was the example of fanfiction.

Drawing from Shannon Farley's research interests, as well as from Lefevere's work, we

discussed the ways that, for example, all of the recent recreations of Sherlock Holmes, both in

4 We made a deliberate choice to base the course on selected readings rather than choosing a book to use as a textbook. Perhaps the most obvious choice for a book to use as an undergraduate textbook is Jeremy Munday's Introducing Translation Studies: Theories and Applications; other texts that provide good overviews of large sections of the field of translation theory are Edwin Gentzler's Contemporary Translation Theories, Susan Bassnett's Translation Studies, and Anthony Pym's Exploring Translation Theories. For overviews of specific areas of translation theory, the series Translation Theories Explored, edited by Theo Hermans and published by St. Jerome, is an excellent resource. Lawrence Venuti's Translation Studies Reader provides a very good starting point for exploring the literature as well. 
No Language Requirement:

Translation Theory in a General Education Context

Strowe and Farley

movies and in television, are examples of rewriting, and can be considered a kind of translation-

especially the BBC's series Sherlock, which reimagines Holmes as a modern consulting

detective in present-day London, with John Watson as his resident "blogger." Sherlock is a

particularly popular source in fandom at the moment, with over 44,000 stories uploaded to the

Archive of Our $O w n^{5}$ as of this writing. Most members of the class had at least passing

knowledge of fandom and fanfiction, with a few clearly having some deeper knowledge of the

subculture. We discussed the ways in which the BBC's production is itself a kind of fanfiction,

since it is based upon a source canon and rewritten by someone other than the original author. In

order to add further scholarly weight to the argument, we also brought in a guest speaker: Rabbi

Rachel Barenblat, a former board member of the Organization for Transformative Works.

Barenblat gave a presentation that was largely based on her 2011 article, "Transformative Work:

Midrash and Fanfiction," in which she argues that, like midrash, fanfiction reimagines source

texts in a way that is almost exegetical. ${ }^{6}$ Fanfiction fills in gaps, answers questions, and

interrogates problematic source texts. Translation, at times, does all these things as well. As an

exercise in finding the limits of the definition of translation, this discussion was fruitful. Most

students were initially unconvinced that fanfiction, or even midrash, "counted" as translation, but

with this discussion we were able to suggest that the scope of translation was broader than the students had previously considered.

Another goal was to create a class vocabulary to talk about what might be and might not

be a translation based on students' gut reactions to the borderline cases that we presented.

5 The Archive of Our Own is a fanfiction archive site run by the Organization for Transformative Works, a nonprofit fandom advocacy group devoted to preserving fandom history and protecting fans' legal rights to creating "transformative" work under copyright precedent.

6 "Midrash" is the term for a genre of exegetical texts in the Jewish tradition that seek to explain or fill in passages from the Tanakh, or Hebrew Bible, usually in a narrative form. The term "midrash" (pl. "midrashim") also indicates a particular work in the tradition. 
No Language Requirement:

Translation Theory in a General Education Context

Everyone, for example, had an opinion about whether "Ladle Rat Rotten Hut" (Chace), a

phonetic rewriting of "Little Red Riding Hood" was a translation even though it stays within a

single language and uses homophony to recall the meaning of other words. ${ }^{7}$ Similarly, we asked

whether Louis and Celia Zukofsky's 1969 phonetic translations of the poetry of Catullus

(Catullus) from Latin to English could legitimately be called translations. From these ideas we

built a new model of what translation is and could be, and what we as a class felt ought to be

excluded. Needless to say, our aim was in part to suggest that the limits of translation were much wider and more vague than our students had previously thought. While we ended with some lingering doubts about some of the more peculiar cases ("Ladle Rat Rotten Hut" was particularly disturbing to some), we also were able to start the next section of the course with students willing to accept a much wider range of literary activities as part of the purview of "translation studies."

\section{Intersemiotic Translation and Rewriting}

It is generally accepted at this point in the discipline of translation studies that the concept of translation can be applied to several different categories of textual modification. In 1959 Roman Jakobson posited three types of translation that are still used today as important distinct typologies of translation: interlingual, or translation proper; intralingual, or paraphrasing; and intersemiotic, in which the texts in question belong to different sign systems, at least one of them non-linguistic (139). Jakobson describes these types of translation as follows:

1. Intralingual translation or rewording is an interpretation of verbal signs by means of other signs of the same language.

\footnotetext{
"Ladle Rat Rotten Hut" is a delightful if confusing exercise in wordplay. When read aloud with proper intonation, the words of "Ladle Rat Rotten Hut" phonetically approximate a telling of "Little Red Riding Hood." For example, the story begins, "Wants pawn term, dare worsted ladle gull hoe lift wetter murder inner ladle cordage, honor itch offer lodge, dock florist" (Chace). Enunciated "correctly," this will sound like "Once upon a time, there was a little girl who lived with her mother in a little cottage, on the edge of a large, dark forest."
} 
No Language Requirement:

Translation Theory in a General Education Context

2. Interlingual translation or translation proper is an interpretation of verbal signs by means of some other language.

3. Intersemiotic translation or transmutation is an interpretation of verbal signs by means of signs of nonverbal sign systems. (139)

While this distinction has allowed many scholars to justify the use of translation theory to analyze cultural products like adaptations or modernizations of various texts, it can also function in the other direction. That is, the inclusion of these types of translation within the rubric of translation studies can not only allow us to use translation theory to explore these texts, but can allow us to use these texts to explore and teach translation theory. This assumption is one of the theoretical bases upon which we built our course. What we have created is essentially a translation studies curriculum based on Jakobson's intralingual and intersemiotic forms of translation, while at the same time taking advantage of the scholarship on interlingual translation to extend the range of the course beyond texts that are accessible to all students. Indeed, we even extend Jakobson's description of intersemiotic translation to include translation between two non-verbal sign systems (for example, a cinematic text translated into a video game), or from a non-verbal system into a verbal one (such as Vermeer's “The Girl with the Pearl Earring” translated into a book and then a film script), the opposite of what he proposes as the definition of intersemiotic translation. Embracing these different types of translation meant that students were all able to contribute to the class no matter what their foreign language skills. Students could bring to the table both experiences of interlingual translation if they had them, but also knowledge about intralingual and intersemiotic translation, which they may not have previously recognized as forms of translation. 
No Language Requirement:

Translation Theory in a General Education Context

Strowe and Farley

Another fundamental concept in our syllabus-and one related to Jakobson's tripartite conception of translation-is the idea of translation as a form of rewriting, posited by André Lefevere, as we note above. Translation as rewriting and, indeed, all of the strategies of rewriting that Lefevere discusses, intersects and overlaps with Jakobson's three types of translation; a rewriting can take place between languages, within a language, or between sign systems. Forms of rewriting include processes of anthologization, historiography, criticism, and editing, all of which are explored by Lefevere. Our focus on rewriting as an ontological framework for translation also corresponds in part to Maria Tymoczko's call to expand the metaphorical and conceptual lenses through which we perceive translation and translation theory. Rewriting suggests valences similar to the idea of translation as anuvad or "speaking after" that Tymoczko discusses in her exploration of worldwide conceptions of translation (Enlarging Translation 6877). Rewriting as a concept challenges the notion of originality, a central concern of translation studies, encouraging the exploration of the source and target texts as related texts, rather than as a text and its derivative. It also allows us to emphasize the agency and power of the translator both as an interpreter of the source text and as a writer in her own right.

Beginning the course with a destabilization of translation also allowed us shift away from simple linguistic analysis as the basis for their thinking about translation. Such a shift has a double purpose. For students who do have a second language, there is a strong tendency to see word-for-word comparisons as the necessary component of any thinking about a translation or about translations in general, and it can be very difficult to help them move beyond this stage. For a similar reason, monolingual students feel that because they do not have a second language, they will be unable to participate in analysis of translations. In a course like ours, the course description was broad and encouraging enough that many students who were not confident in a 
No Language Requirement:

Translation Theory in a General Education Context

Strowe and Farley

second language were willing to enroll, but we still needed to convince them that they would be able to contribute to the class and to perform the kinds of analysis that we were asking of them.

\section{Pseudotranslation}

One of the other tools we used to accomplish this shift was the notion of pseudotranslation. ${ }^{8}$ A pseudotranslation is a text that is presented as a translation in a given culture, but for which there is actually no source text. That is, in terms of a textual exchange between two languages or cultures, it is not a translation at all. In terms, however, of the cultural significance of translation, of the position that translations can occupy in a culture, the reasons that one might translate, the power dynamics between two communities, and many other nonlinguistic and non-textual concerns, pseudotranslations essentially function just like translations. They are, like translations, "facts" of their culture, as Gideon Toury observes (40-52).

The key aspect of the study of pseudotranslation in a monolingual classroom is that given the notion of pseudotranslation, students are freed from the idea that they must speculate about the content, tone, significance, culture, or other characteristics of a text in a language they do not know, since by definition there is no foreign-language source text. This freedom from a source text could certainly be seen as a narrowing of the field of discussion, since it eliminates one of the two texts usually in question in a discussion of translation. It also, however, allows discourse about translation in the classroom to move beyond the limiting concern of "faithfulness" or "fidelity," challenging students to come up with ideas about what one talks about when unable to discuss the actual translation choices surrounding particular words, phrases, or structures. A discussion of pseudotranslation can never be reduced to the comparison of texts. It forces the discussion beyond these linguistic concerns and into the wider field of the cultural significance

8 G.C. Kálmán (69) lists pseudotranslations as the first case in his article on borderline cases of translation, and Gideon Toury discusses their significance as a literary phenomenon related to translation in his Descriptive Translation Studies and Beyond (40-52). 
No Language Requirement:

Translation Theory in a General Education Context

of "translation" as a product, a literary form, and a practice. Our discussion of pseudotranslation

was more theoretical than applied; we introduced the notion and some examples that were briefly explained, but did not require students to read any pseudotranslations.

Our examples included James Macpherson's 1760 Fragments of Ancient Poetry,

\section{Collected in the Highlands of Scotland, and Translated from the Galic or Erse Language}

(Macpherson), presented by Macpherson as a translation of poems by the Scots bard Ossian, whose work and whose existence Macpherson had invented. Macpherson's work aimed at establishing Scots folklore as a literary tradition parallel to that of the Ancient Greeks, and came at a particularly key time in the creation of Scottish identity within the British Empire. Another example was George Gascoigne's Adventures of Master F.J., which was published as part of a collection in 1573 as an original tale and then republished in 1575 as a translation from the "Riding Tales" of a fictional Italian named "Bartello" (Gascoigne Posies and Hundreth Sundrie Flowres). Gascoigne's work can be seen in the context of Renaissance English borrowings from Italian literature as well as the crisis of morality and religion that was taking place. In both cases, it is obviously not possible to revert to discussion of linguistic translation choices, or to claim that such analysis would be necessary, since there is no source text. Instead, the discussion must focus on what it means to be a translation in those cultures and those historical moments, and how the notion of translation itself is implicated in that meaning. There is no original to which to compare the "translation," and discussion thus focuses on the implications of the writing itself.

\section{Internet Culture, Memes, and Translation}

Challenging the notion of originality is a hermeneutic that appeals to students who have grown up in an age where internet culture not only facilitates but encourages infinite 
No Language Requirement:

Translation Theory in a General Education Context

Strowe and Farley

permutations of ideas in the form of memes. ${ }^{9}$ Internet culture offers not only various literary text

types-the facebook status, the tweet, the FAQ, the lolcat meme ${ }^{10}$-but different language systems

that illustrate Jakobson's types of translation. The language of the lolcat meme, for example, has

its own internal consistency and semiotic markers (Dash). Part of our process in presenting

translation theory involves allowing students to integrate their knowledge of internet texts and

cultures into the discussion of translation by broadening our idea of what constitutes text and

what kinds of texts and textual manipulation constitute permissible areas of study for translation

theory.

Significantly for the monolingual students and for our idea of a potentially monolingual

translation classroom, this included a willingness to accept Jakobson's intralingual and

intersemiotic translation not only as creative renamings of "modernization" or "adaptation" but

also as legitimately translational literary activities. ${ }^{11}$ We anticipated that this would be an

important theoretical point that would allow our students to develop their own ideas about

translation independent of their language abilities.

9 Coined by Richard Dawkins in The Selfish Gene (1976; chapter 11), "meme" has come to mean any replicated cultural symbol, and further, the "viral" textual structures (or, more recently, combinations of text and picture) that make up the common language of the internet. Examples include "rickrolling," "I'm in your X, Ying your Z," "pwned," or, more recently, "ermahgerd" in place of OMG. It is worth noting here that before the word "meme" entered popular use on the internet, the translation scholar Andrew Chesterman had already adopted the vocabulary of memes to discuss the evolution and transmission of ideas about translation. Chesterman's analysis, however, focuses on memes to explain the viral movement of discourses about translation, rather than examining, as we do here, the notion of the internet meme as a product of a translational process.

10 The lolcat meme is a form of internet cultural production that combines a picture of a cat, often doing something entertaining, with a humorous caption, written in a linguistic form heavy with abbreviations and particular types of misspelling, and traditionally presented in "impact" font.

11 We use the terms "adaptation" and "modernization" in a non-technical sense as textual activities that students do not always see initially as particularly tied to translation. While not denying that these topics merit particular attention on their own terms, we focus on how the shifting dialects, registers, and non-linguistic semiotic markers involved in both adaptation and modernization are fundamentally translational and can be discussed at least partly with the vocabulary of translation theory. There is a significant body of work on adaptation in particular. See for example the journal Adaptation out of Oxford Journals, as well as Adaptation Studies: New Approaches, edited by Christa Albrecht-Crane and Dennis Cutchins, and Redefining Adaptation Studies, edited by Dennis Cutchins, Laurence Raw, and James M. Welsh. 
No Language Requirement:

Translation Theory in a General Education Context

Strowe and Farley

In Spring 2012, we followed the section on expanding ideas of translation with a unit that showed some of the political, social, and cultural applications of translation studies, and then returned to more traditional readings from translation theory with Jakobson. In Fall 2012 and Spring 2013, the Jakobson reading and other traditional approaches to translation theory (Friedrich Schleiermacher, Eugene Nida, J.C. Catford, e.g.), were taught earlier in the semester to introduce a wider vocabulary that students could then use to explore the implications of translation in the wider world. This change also encouraged students to talk about intralingual or intersemiotic translations early in the course and thus reinforced the idea of the first few weeks that translation is a larger concept than they had perhaps realized.

This understanding of how intralingual translation can demonstrate similar traits as interlingual translation and be discussed using the same methods and vocabulary manifested itself particularly in one of the two major projects, in which students were asked to translate a text and provide a 5-6 page translator's note to accompany their translation. ${ }^{12}$ This is perhaps a startling assignment, given that we knew that many of our students were functionally monolingual, but the assignment explicitly included the possibility of writing intersemiotic or intralingual translations. We asked all of the students to come speak to their discussion section instructor about their topic before beginning, so that we could help them decide how much text was enough to satisfy our requirements (it differed depending naturally on whether it was poetry or prose, and what the students' intents were regarding their translations, including their stated goals for the translation, intended audiences, creative translation strategies, reasons for choosing particular texts or genres, and their own linguistic or stylistic goals) and so that we had an idea of

12 In Spring 2012, this project was the final project of the semester; in Fall 2012 it was repositioned as the midterm project. The change was prompted in part by students' suggestions that the other project be the final project to give them more time and scope for their research, and in part to give students an opportunity to try their hand at a longer translation than we had done in discussion sections midway through the semester so that they had first-hand experience on which to draw for the remainder of the course. 
No Language Requirement:

Translation Theory in a General Education Context

Strowe and Farley

what kinds of projects were being attempted and how we could best help them accomplish them.

Many of the projects in Spring 2012 were interlingual, but quite a number were intralingual, including modernizations and translations into different literary and cultural styles. One student, using some of the "linguistic" resources from a similar internet project to translate the whole Bible, translated the Book of Nahum into lolcat. In Fall 2012, an even higher proportion of translation projects were intralingual, including a cultural translation of a scene from the movie The Breakfast Club from a suburban into an inner city setting; a translation of several chapters from the biblical Book of Revelation into the style of Dr. Seuss; a translation of two NPR movie reviews into tumblr fangirl speak; ${ }^{13}$ and a translation of Priam's request for Hector's body from the Iliad based not on the Greek (the student had no Ancient Greek at all), but from three different published translations.

The opportunities offered by intralingual translation were taken not only by the monolingual students but also by students who, although they had studied another language, did not feel confident enough to use it for their translation project. The student who translated the Book of Nahum into lolcat, for example, had taken four semesters of German but asked if she could work on an intralingual project because she was not sure that she would be able to engage in a complex discussion of tone, idiom, voice, and genre regarding a German text. Her discussion of the process through which she decided to translate into lolcat was engaging and well-thought out; she described how in her thinking about the final project, she realized that she knew a

13 Tumblr fangirl speak is, like lolcat, an internet phenomenon that combines elements of English, often misspelled and ungrammatical, with its own particular set of other semiotic markers. It comes from the textual habits of fannish communities on the website tumblr (which tends towards a youthful demographic), a site based on the ability to "reblog" items of interest, creating chains of cultural transmission that carry with them their textual conventions. There is a large body of abbreviations, which are mainly what an internet search for "tumblr fangirl speak" will turn up, but the form has many other characteristics as well. It tends to be written in short, unpunctuated sentences, each standing as its own paragraph. Other conventions, such as the "keysmash" (asdhlb;ew;oesdfjk) or sentences written in all capitals, are used to express various emotions or attitudes towards the author's subject. The student's work in this translation focused largely on an analysis of the cultural capital and textual expectations of the source and target audiences and the linguistic and cultural information that each text needed to convey or could safely omit. 
No Language Requirement:

Translation Theory in a General Education Context

language other than English and German, and one that she was much more familiar with than

German: lolcat. Leaving aside the question of whether lolcat is a dialect, a language, or a fad, her analysis of her translation was exceptional, including a discussion of her choice to bring in references to other internet memes in order to situate her translation within the framework of internet culture, which she saw as a cultural system possessing its own generic and stylistic conventions (lolcat being only one example) as well as a range of possibilities for intertextuality.

\section{Interlingual Translation}

The consequences of a pedagogy that accepts the possibility of monolingual students as well as students who have studied other languages is significant when teaching translation theory in a Comparative Literature or English general education setting, where students may have a wide range of language abilities. Even given a course with a prerequisite of a language course above a certain level (third year, for example), will likely have students of varying levels of familiarity with their chosen languages and cultures. The University of Massachusetts has a language requirement for admissions for entering freshmen (2 years of the same language in high school), and most departments also require at least two semesters of language study. Even such requirements, however, are no guarantee of an adequately high level of language proficiency for nuanced interlingual translation practice or analysis. An insistence on interlingual translation and multilingual practice, both in class discussion and in student assignments, would potentially limit students whose language abilities are not as high to struggling largely with language and culture rather than interacting fully with the concerns of translation theory. Allowing students to choose intralingual projects, and providing them with examples that were readily understandable without a strong grounding in a foreign language and culture, permitted them to engage with the theory that is the main point of the class, rather than foundering on linguistic issues that are more 
No Language Requirement:

Translation Theory in a General Education Context

Strowe and Farley

properly the province of language learning. ${ }^{14}$ The critical phrase "competence in a language other than English is helpful, but not necessary" was added to the course description both because of our desire to advertise the class as not only for students with proficiency in a foreign language and because of a specific request from the General Education approval board that we be more clear about the prerequisites.

In order, however, for all students to have the experience of translating from a different language and culture, and to complete this exercise on an equal footing with their peers, we borrowed a technique from Maria Tymoczko, who gives her students translation exercises in which they must translate from Old Irish, a language one can usually count on nobody in the class knowing. The exercise can be done with nobody in the course, including instructors, being familiar with the language and culture. The idea of the exercise is to recreate a portion of the decision-making process of translation with a finite set of information about a particular text.

The information is accessible through Tymoczko's descriptions of the exercises, which are more detailed than ours here, and indeed, if the instructor has only the same amount of information as the students, there is no possibility that students will feel constrained by a sense that the instructor has privileged linguistic and cultural knowledge that allows him or her to know the "correct" translation or the "right" approach. The goal of the assignment was two-fold: to give students the opportunity to translate a poem without feeling constrained by their own foreign language skills and to demonstrate the wide variety of "solutions" that can be applied to such a translation by prompting a discussion about the choices and strategies that students had used.

\footnotetext{
${ }^{14}$ This is not to suggest that translation can be reduced to linguistic skill. Rather, because we recognize that such a reduction is often tempting to students and others, we use intralingual translation to help students gain an understanding of the many non-linguistic factors involved in translation.
} 
No Language Requirement:

Translation Theory in a General Education Context

Strowe and Farley

These exercises involved the translation of two poems, "Int én bec" and "Ro-cúala," from

Old Irish. ${ }^{15}$ In each case, we provided students with a word-for-word translation of the poem as

well as material explaining the cultural and textual aspects of the poem. The first poem is a 24-

syllable Irish nature poem about a blackbird singing over a loch, which uses imagery associated

with war and catastrophe in medieval Irish culture. ${ }^{16}$ The poem has a very strict formal structure,

with eight three-syllable lines and a precise rhyming pattern. The second is a humorous four-line

poem with a formal structure of one three-syllable line followed by three eight-syllable lines.

This poem mocks a chief for his lack of generosity toward poets, and disrupts its own formal structure by truncating the last line to one syllable for a dramatic and humorous ending. ${ }^{17}$

We did the translation of the first poem as an assignment for an early discussion section

(in week 3) and the second later in the semester (week 9) in Spring 2012. For the first poem, many students chose to translate into their non-native languages, which made the discussion occasionally difficult, since they could not always discuss their choices with the kind of nuance that they would have had they translated into their native languages. Of course, these translations did prompt discussions of interesting facets of other languages and literatures, for example the ability of Classical Chinese to accommodate very well the strict syllabic patterns of "Int én bec." The exercise, however, did not depend on anyone's knowledge of another language, and would have been similarly productive had all students been monolingual English native speakers rendering the poem in English. By the time we assigned the second translation, we had spent many weeks emphasizing the translator's agency in translation and examining both the

15 Tymoczko describes the use of these activities in her graduate classes on translation studies in Englarging Translation, Empowering Translators ("Int én bec," 266-76) and Translation in a Postcolonial Context ("Ro-cúala," 51-4), where she also provides examples of some of the resulting translations.

16 From Gerard Murphy's translation of "Int én bec" in Early Irish Lyrics (7): "The little bird which has whistled from the end of a bright-yellow bill: it utters a note above Belfast Loch--a blackbird from a yellow-heaped branch."

17 From Gerard Murphy's translation of "Ro-cúala" in Early Irish Lyrics (91): "I have heard that he gives no steeds for poems; he gives what is native to him, a cow." 
No Language Requirement:

Translation Theory in a General Education Context

borderline translation cases discussed above and examples of more traditional translation that showed significant ideological, cultural, or political modification by the translator. This background combined with the students' increasing comfort with experimenting within the class and the humor of the poem itself, led to much more adventurous translations, in which students chose much more freely the aspects they wished to preserve from the source poems and did so in creative ways.

In the second and third semesters that this course was offered, "Ro-cúala" was assigned in week 3 , and in future courses we may return to the translation at the end of the course to see how students' thoughts on translation and their own creative processes change through the course, and to allow students to return to an earlier project with new ideas. Assigning "Ro-cúala" early worked better than "Int én bec" as an exercise, perhaps because students found the humorous content of the poem more easy to approach in creative ways than the unfamiliar poetics of the nature poem. Students seemed comfortable accepting that "humor" could be a characteristic of a text that could only be preserved in translation with significant changes to other aspects of the text, and it is possible that their difficult translating the nature poem was in part because of a view of such poetry as somehow more "authorial" and less subject to cultural change. One student's translation, for example, updates the notion of patronage of the arts in order to retain the humor:

His favorite record label

Released for free - said "donate what you're able" He did as much as he thought warranted: Torrented. $^{18}$

We suggest above that the instructor need not have any familiarity with Old Irish in order to borrow these exercises from Maria Tymoczko. A similar exercise could, however, be

\footnotetext{
${ }^{18}$ We reproduce this poem here with the permission of the author, Caroline Marsden.
} 
No Language Requirement:

Translation Theory in a General Education Context

constructed with a short text from any language the instructor might choose and could provide the same type of linguistic, literary, and cultural information for in order for students to work on translating that text. Other permutations are also possible. If the language of the text is shared by some but not all of the students, a first half of the exercise could be for the students who can read the text to compile whatever information they deem pertinent to the text so that students without that language could then translate. This could be done as homework assignments, in small groups or pairs, or as a class through discussion.

We were even able to create monolingual exercises to give students experience with some of the skills necessary for simultaneous, consecutive, and conference interpreting in a week dedicated to interpreting studies toward the end of the semester. These types of exercises are used in interpreter-training courses as ways to prepare these skills independently of each other, but for our purposes they also allowed us to give students a taste of the challenges of interpreting without either a common second language in the classroom or even fluency in a second language on the part of individuals. They included memory games, exercises in note-taking and subsequent re-articulation of passages of text, and what we jokingly called "simultaneous telephone" in groups of three, where one student had to listen to a partner reading a text aloud and, with a delay of several seconds, relay the same text in the same language to a third student. While we are under no illusions that this very brief excursion into interpreting could prepare students for the practice of interpreting, it gave students enough first-hand experience with some of the aspects that differentiate translation from interpreting for a useful discussion. ${ }^{19}$

\section{Intralingual Translation}

19 The University of Massachusetts also offers a two-course sequence on interpreting that does have a language requirement and teaches both interpreting studies and practical aspects of consecutive and simultaneous interpreting. Students from our classes who were interested in pursuing interpreting were encouraged to consider these classes. 
No Language Requirement:

Translation Theory in a General Education Context

We also used intralingual examples to approach theoretical questions regarding translation and text. In week eight of the Spring 2012 class, we approached issues of tone, idiom, and voice by having the students read excerpts from J.C. Catford's A Linguistic Theory of Translation: An Essay in Applied Linguistics and Theo Hermans's “The Translator's Voice in Translated Narrative.” Hermans's article discusses the artifacts that a translator's voice can leave behind in a translated text--artifacts that a reader does not need a second language to identify. ${ }^{20}$ The translator's voice itself is a "discursive presence" in the translations we read, and we can comment upon their presence and the implications for the practice of translation. Catford's work goes further to give our monolingual students tools to not only identify idiolect, dialect, register, style, and mode in a source text, but to use those linguistic varieties to translate interlingually. We discuss the personal idiolects of particular characters (Forrest Gump serves as a good example) and the way dialect is used in Fargo, as well as temporally-based dialect shifts such as those between Beowulf, Chaucer, Shakespeare, and the present day.

This foundation offers our monolingual students options when the time comes to write their translation project. Among the students who took advantage of this opportunity in Spring 2012 was one who translated the first few pages of Charles Dickens's A Christmas Carol into the style of Ernest Hemingway. The student accomplished this largely by converting Dickens's long periods into the short, punchy sentences that characterize Hemingway's work as well as altering the vocabulary and register of the text. Another, coincidentally, translated a section of The Sun Also Rises into the style of a rap song. These projects, while not translations from one distinct linguistically-defined "language" to another, gave these monolingual students the experience of translating from a source language to a target language by utilizing the linguistically

20 Discovering these artifacts is part of the practice of reading in translation discussed by Venuti and Wittman and Windon. 
No Language Requirement:

Translation Theory in a General Education Context

differentiated categories of "dialect" and "register." Further, in giving the students such practical experience of translating, their understanding of the underlying theory is enhanced. By the end of the semester when the translation projects were assigned and completed, there were few, if any, students who persisted in the belief that an intralingual translation did not "count" as translation.

\section{The Implications and Applications of Theory}

These texts and exercises formed a basis of understanding translational movement for our students. Another part of the course, aimed at analyzing, testing out, and exploring both the validity and the implications of various theoretical models was aimed at examining the role of translation in the world. Given a broad framework for what kinds of textual transfer might constitute translation, even without knowledge of another language, students were able to approach questions of politics, gender, colonialism, and cultural interface as seen through a variety of texts, with the tools from translation studies to help them describe both the textual and the cultural transformations that they saw taking place, as well as the significance of those changes. In addition, we occasionally invited other translators and various scholars to come talk to the class about their particular work. A few particularly useful guest lectures included Ellen Elias-Bursac's lecture about her experience translating for the War-Crimes Tribunal in The Hague; Faith Conant's lecture about the intersection of dance, poetry, and drum language in the Ewe tradition in Western Africa; and Ethan Zuckerman's lecture about global translation practices online. These additional perspectives to our conversation about translation and translation theory gave the students ample evidence that what we were teaching them had wide application, and that our way of perceiving and discussing translation was not unique to UMass or to their instructors. Such a lecture series could be put together with faculty from almost any institution, on topics from immigration law or communication in the E.U. to multilingualism, 
No Language Requirement:

Translation Theory in a General Education Context

Maghrebi literature, or film adaptations. Although we were lucky to have available some speakers who work in translation studies, not all of our speakers did, and part of our challenge to students was to see how they could fit the ideas presented by speakers about language and communication into the theoretical frameworks discussed in class.

The project we asked students to complete in Spring 2012 as a midterm project, an analysis of two texts, one of which is an intersemiotic translation of the other, figured in Fall 2012 and Spring 2013 as a final project showcasing the analytical skills that they learned through the semester. ${ }^{21}$ It was, in part, the students themselves who prompted the change in the project's timing; we received feedback both right after the assignment and in course evaluations from Spring 2012 saying that the students wanted more time and more space to complete their analyses, and would prefer to have the project assigned, with a higher page count, as a final project. The work that they did on this assignment the first time the course was offered also suggested that they needed a little more experience with discussing translations before tackling such an assignment, although their results were nonetheless impressive. Like the projects in intralingual translation, the intersemiotic assignment gives space to all students, not only those who are monolingual, to look closely at how translational phenomena affect textual transmissions and the relationships between text and culture more broadly.

Many students chose the relationship between a book and a movie made from that book (Great Gatsby, Taming of the Shrew, Keigo Higashino's Tegami, for example). Other students moved further afield and into other media. The recent video game Dante's Inferno was one of the texts for one student's paper, the other being an English translation of Dante's Inferno. Another student discussed Alice in Wonderland and the Walt Disney World ride based on it as an

21 This exercise was suggested by Maria Tymoczko, who had used it in a higher level undergraduate course with great success. 
No Language Requirement:

Translation Theory in a General Education Context

intersemiotic translational pairing. One paper addressed the painting inspired by Great Gatsby, used as the cover of the first edition, as a translation of the novel. Another made the case for a description of a performance of the piano reduction of Wagner's opera Tristan und Isolde, found in Thomas Mann's short story “Tristan,” as a form of translation.

\section{Conclusion}

The course has been quite a success, both in terms of teaching students the fundamentals of translation theory and, more broadly and perhaps more widely applicable to English Departments, methods of close reading, textual interpretation, and cultural awareness. One student wrote in the final evaluation that the course "changed my perspective on translating, literature, and culture in general," and several others told us that they now saw translation everywhere, and were constantly thinking about how to interpret cultural artifacts through the lens of translation studies. In each semester, we were able to watch students' ability to interpret text improve from week to week, as they learned more ways to discuss and think about translation and translated texts.

Whether in English Departments, Comparative Literature, or national language departments, the study of translation can lead to increased sophistication in discussing text, interpretation, and cultural encounters, as many instructors have realized. We suggest this course as one of the possible tools to leverage such knowledge, either in conjunction with or independent of courses like that discussed by Emily O. Wittman and Katrina Windon. In particular, our methodology allowed us to introduce monolingual students as well as those with second and even third languages to the intricacies of contemporary translation theory, while at the same time allowing them to further develop the interpretive skills and cultural understandings promoted by English and world literature programs--tools that they can use both in their own 
No Language Requirement:

Translation Theory in a General Education Context

intellectual lives and as members of an increasingly global, and translational, society. Supplying

such tools is ultimately the goal of a liberal arts education, and should be among the goals of

every general education class.

\section{Appendix A}

Each time we taught the course it was divided into units of two or three weeks that shared a common theme or set of approaches. We list the units here with some keywords describing the topics covered in each.

Spring 2012

Unit 1: What is translation? What is adaptation? What is a language?

Unit 2: Translation and Global Culture Wars (politics, global English, computer translation)

Unit 3: Meaning and Translation (where does meaning reside in text? how do we find it?)

Unit 4: Theoretical Approaches to Translation (Schleiermacher, Catford, Jakobson, Nida, etc.)

Unit 5: Beyond Translation (international ideas of translation, interpreting studies)

Fall 2012 and Spring 2013

Unit 1: What is translation? What is adaptation? What is a language?

Unit 2: Early Theoretical Approaches to Translation and Meaning (Schleiermacher, Catford, Jakobson, Nida, etc.)

Unit 3: Culture, Language Drift, and Global Technology (computers, globalization)

Unit 4: Politics and Ideology (postcolonial theory, gender studies)

Unit 5: Interpretation, Ethics, and Agency (interpreting, ethical questions for both translators and translation scholars)

Unit 6: Beyond Western Translation Theory (concept formation, international theory, orality)

\section{Appendix B}

The following bibliography is the reading list for the third edition of the course, in Spring 2013, including several works that were not assigned to students but were discussed during class.

Alexieva, Bistra. 2001. “A Typology of Interpreter-Mediated Events.” In The Interpreting

Studies Reader. Ed. Franz Pöchhacker and Miriam Shlesinger. London: Routledge. 219-33.

American Translators Association. "Code of Ethics and Professional Practice."

http://www.atanet.org/membership/code_of_ethics.php

---. "Commentary." http://www.atanet.org/membership/code_of_ethics_commentary.pdf

Anderson, R. Bruce W. 2001. "Perspectives on the Role of the Interpreter." In The Interpreting

Studies Reader. Ed. Franz Pöchhacker and Miriam Shlesinger. London: Routledge. 209-17.

Baker, Mona. 2002. "Editorial Statement." The Translator. 8.2.

---. "Personal Statement." http://www.monabaker.com/personalstatement.htm 
No Language Requirement:

Translation Theory in a General Education Context

Strowe and Farley

Ben-Ari. 2010. "Reclaiming the Erotic: Hebrew Translations from 1930 to 1980." In

Translation, Resistance, Activism, ed. Maria Tymoczko. Amherst: University of

Massachusetts. 129-148.

Borges, Jorge Luis. "Pierre Menard, Author of Don Quixote.” Trans. Anthony Bonner. In Ficciones. New York: Grove Press, 1962. 45-55.

Catford, J. C. 1965. A Linguistic Theory of Translation: An Essay in Applied Linguistics. London: Oxford University Press.

Chace, H.L. 1956. Ladle rat rotten hut. Pittsburgh, PA: Oldstyle Press.

Chamberlain, Lori. 2004. "Gender and the Metaphorics of Translation." In The Translation Studies Reader. $2^{\text {nd }}$ Ed. Ed. Lawrence Venuti. New York and London: Routledge. 306-21

Cheung, Martha P. Y. 2006. "From 'Theory' to 'Discourse': The Making of a Translation Anthology." Translating Others. Ed. Theo Hermans. 2 vols. Manchester: St. Jerome. 1.87-101.

Cheyfitz, Eric. 1997. "Chapter 4: Translation, Transportation, Usurpation." The Poetics of Imperialism: Translation and Colonization from The Tempest to Tarzan. Philadelphia: University of Pennsylvania Press

Even-Zohar, Itamar. 1990. Polysystem Studies. Poetics Today 11 no. 1, special issue.

Fenton, Sabine, and Paul Moon. 2002. "The Translation of the Treaty of Waitangi: A Case of Disempowerment." Translation and Power. Ed. Maria Tymoczko and Edwin Gentzler. Amherst: University of Massachusetts Press. 25-44.

Gentzler, Edwin. 2007. Translation and Identity in the Americas. New York: Routledge. Gile, Daniel. 2001. "Conference Interpreting as a Cognitive Management Problem.” In The Interpreting Studies Reader. Ed. Franz Pöchhacker and Miriam Shlesinger. London:

Routledge. 163-76.

Hermans, Theo. 1996. “The Translator's Voice in Translated Narrative.” Target: International Journal of Translation Studies. 8 (1): 23-48.

---. 1999. Translation in Systems. Manchester: St. Jerome.

Holmes, James S. 1994. Translated! Papers on Literary Translation and Translation Studies.

2nd. ed. Amsterdam: Rodopi.

Jakobson, Roman. 2004. "On Linguistic Aspects of Translation." In The Translation Studies

Reader. $2^{\text {nd }}$ Ed. Ed. Lawrence Venuti. New York and London: Routledge. 138-43.

Kálmán, G.C. "Some Borderline Cases of Translation.” New Comparison 1 (1986), 117-22.

Larrien, Duane. 1984. "The Dictionary: Help or Hindrance for the Translator.” Translation Review. 22-28.

Lederer, Marianne. 2001 "Simultaneous Interpretation-Units of Meaning and Other Features.” In The Interpreting Studies Reader. Ed. Franz Pöchhacker and Miriam Shlesinger. London:

Routledge. 131-40.

Lefevere, Andre. 1992. Translation, Rewriting, and the Manipulation of Literary Fame. London: Routledge.

Lianeri, Alexandra. 2006. "Translation and the Language(s) of Historiography: Understanding Ancient Greek and Chinese Ideas of History." Translating Others. Ed. Theo Hermans. Manchester: St. Jerome Press. 67-86.

Luton, Lisette. 2003. "If the Computer Did My Homework, How Come I Didn't Get an 'A'?" The French Review. 76.4, 766-70.

Mehanna, Tarek. 2012. "Statement Upon Being Sentenced to 17 Years in Prison" Washington Report on Middle East Affairs. http://www.washington-report.org/archives/512-washington- 
report-archives-2011-2015/june-july-2012/11226-what-they-said-statement-upon-beingsentenced-to-17-years-in-prison.html

Nida, Eugene A. 1964. Toward a Science of Translating: With Special Reference to Principles and Procedures Involved in Bible Translating. Leiden: E. J. Brill.

Pöchhacker, Franz. 2004. Introducing Interpreting Studies. London: Routledge.

Pua'ala'okalani D. Aiu. 2010. “Ne'e Papa I Ke O Mau: Language as an Indicator of Hawaiian

Resistance and Power." In Translation, Resistance, Activism, ed. Maria Tymoczko. Amherst: University of Massachusetts. 89-107.

Quine, Willard V. O. 1959. "Meaning and Translation.” On Translation. Ed. Reuben A. Brower. Cambridge: Harvard University Press. 148-72.

Schleiermacher, Friedrich. 2004. "On the Different Methods of Translating." In The Translation Studies Reader. ${ }^{\text {nd }}$ Ed. Ed. Lawrence Venuti. New York and London: Routledge. 43-63.

Seleskovich, Danica. 2001. "Language and Memory: A Study of Note-Taking in Consecutive Interpreting." In The Interpreting Studies Reader. Ed. Franz Pöchhacker and Miriam Shlesinger. London: Routledge. 121-29.

Susam-Sarajeva, Sebnem. 2002. "A 'Multilingual' and 'International' Translation Studies?' Crosscultural Transgressions: Research Models in Translation Studies II: Historical and Ideological Issues. Ed. Theo Hermans. Manchester: St. Jerome. 193-207.

Toury, Gideon. 1995. Descriptive Translation Studies and Beyond. Amsterdam and Philadelphia: John Benjamins.

Tymoczko, Maria. 1990. "Translation in Oral Tradition as a Touchstone for Translation Theory and Practice." In Translation, History and Culture. Ed. Susan Bassnett and André Lefevere. London: Pinter. 46-55.

---. 1999. Translation in a Postcolonial Context: Early Irish Literature in English Translation. Manchester: St. Jerome.

---. 2007. Enlarging Translation, Empowering Translators. Manchester: St. Jerome.

---. 2010. "Translation Theory." Encyclopedia of Applied Linguistics. Wiley-Blackwell, online. Venuti, Lawrence. 2008. The Translator's Invisibility. 2nd edition. London: Routledge.

Vieira, Else Ribeiro Pires. 2010. "Growing Agency: The Labors of Political Translation." In Translation, Resistance, Activism, ed. Maria Tymoczko. Amherst: University of Massachusetts.

\section{Works Cited}

Adaptation. Journal of the Association of Adaptation Studies. Oxford Journals. Oxford: Oxford University Press, 2008-.

Albrecht-Crane, Christa and Dennis Cutchins. Adaptation Studies: New Approaches. Madison, NJ: Farleigh-Dickinson University Press, 2010.

American Literary Translators Association. "Academic Programs.” 2010. Web. Accessed 9 Jan. 2013. <http://www.utdallas.edu/alta/resources/academic-programs>.

American Translators Association. "ATA Institutional Members Offering Translation/Interpreting Courses." 2012. Web. Accessed 9 Jan. 2013. $<$ http://www.atanet.org/careers/T_I_programs.php>. 
No Language Requirement:

Translation Theory in a General Education Context

Apter, Emily. 2005. The Translation Zone: A New Comparative Literature. Princeton: Princeton University Press.

Archive of Our Own. Organization for Transformative Works, n.d. Web. 28 Oct. 2012.

Barenblat, Rachel. "Transformative Work: Midrash and Fanfiction." Religion and Literature 43.2 (2011), 171-177.

Bassnett, Susan. Translation Studies. 3rd edition. London: Routledge, 2002.

Bassnett, Susan, and André Lefevere. 1990. Translation, History and Culture.

Borges, Jorge Luis. "Pierre Menard, Author of Don Quixote.” Trans. Anthony Bonner. In

Ficciones. New York: Grove Press, 1962. 45-55.

Campe, Gertrud Graubart. Programs in Translation Studies: An ATA Handbook. Alexandria,

VA: American Translators Association, 2002.

Catford, J. C. A Linguistic Theory of Translation: An Essay in Applied Linguistics. London:

Oxford University Press, 1965.

Catullus, Gaius Valerius. Catullus (Gai Valeri Catulli Veronensis Liber). Trans. Louis and Celia Zukofsky. London: Cape Goliard Press, 1969.

Chace, H.L. Ladle rat rotten hut. Pittsburgh, PA: Oldstyle Press, 1956.

Chesterman, Andrew. Memes of Translation: The Spread of Ideas in Translation Theory.

Amsterdam: John Benjamins, 1997.

Cutchins, Dennis, Laurence Raw, and James M. Welsh, eds. Redefining Adaptation Studies.

Plymouth: Scarecrow Press, Inc., 2010.

Damrosch, David. What is Translation? Princeton: Princeton University Press, 2003.

Dash, Anil. "Cats Can Has Grammar." A Blog About Making Culture. 2007. Web. $<\mathrm{http}: / /$ dashes.com/anil/2007/04/cats-can-has-gr.htmls

Dawkins, Richard. The Selfish Gene. Oxford: Oxford University Press, 1989.

Gascoigne, George. A Hundreth Sundrie Flowres. Oxford: Clarendon Press, 2000.

---. The Posies. Cambridge: at the University Press, 1907.

Gentzler, Edwin. Contemporary Translation Theories. Revised 2nd edition. Clevedon: Multilingual Matters, 2001.

Hermans, Theo. "The Translator's Voice in Translated Narrative." Target: International Journal of Translation Studies 8.1 (1996), 23-48.

Jakobson, Roman. “On Linguistic Aspects of Translation.” In The Translation Studies Reader. 2nd Ed. Ed. Lawrence Venuti. New York and London: Routledge. 138-43, 2004.

Kálmán, G.C. "Some Borderline Cases of Translation." New Comparison 1 (1986), 117-22.

Lefevere, André. Translation, Rewriting, and the Manipulation of Literary Fame. London: Routledge, 1992.

Macpherson, James. 1966. Fragments of Ancient Poetry. Ed. by John J. Dunn. Los Angeles: William Andrews Clark Memorial Library, Augustan Reprint Society.

Maier, Carol, and Françoise Massardier-Kenney. Literature in Translation: Teaching Issues and Reading Practices. Manchester: St. Jerome, 2010.

Massardier-Kenney, Françoise. 2010. "Translation Theory and Its Usefulness.” In Literature in Translation: Teaching Issues and Reading Practices. Ed. Carol Maier and Françoise Massardier-Kenney. Manchester: St. Jerome. 22-30.

Munday, Jeremy. Introducing Translation Studies: Theories and Applications. London: Routledge, 2001.

Nida, Eugene A. Toward a Science of Translating: With Special Reference to Principles and Procedures Involved in Bible Translating. Leiden: E. J. Brill, 1964. 
No Language Requirement:

Translation Theory in a General Education Context

Pym, Anthony. Exploring Translation Theories. London: Routledge, 2010.

Schleiermacher, Friedrich. "On the Different Methods of Translating." In The Translation Studies Reader. 2nd Ed. Ed. Lawrence Venuti. New York and London: Routledge, 2004 . 4363.

Toury, Gideon. Descriptive Translation Studies and Beyond. Amsterdam and Philadelphia: John Benjamins, 1995.

Tymoczko, Maria. Enlarging Translation, Empowering Translators. Manchester: St. Jerome, 2007.

---. Translation in a Postcolonial Context: Early Irish Literature in English Translation. Manchester: St. Jerome, 1999.

--- "Translation Theory." Journal of Applied Linguistics. Wiley-Blackwell. 2013. Web.

Venuti, Lawrence. "Translation and the Pedagogy of Literature." College English 58.3 (Mar. 1996), 327-344.

--- The Translation Studies Reader. 2nd edition. London: Routledge, 2004.

Wittman, Emily O. and Katrina Windon. "Twisted Tongues, Tied Hands: Translation Studies and the English Major." College English 72.5 (May 2010), 449-69. 